\title{
Refining Estimates of Fuel-Cycle Greenhouse-Gas Emission Reductions Associated with California's Clean Vehicle Rebate Project with Program Data and Other Case-Specific Inputs
}

\author{
Nicholas Pallonetti * and Brett D. H. Williams \\ Center for Sustainable Energy (CSE), 3980 Sherman St. Suite 170, San Diego, CA 92110, USA; \\ brett.williams@energycenter.org \\ * Correspondence: nicholas.pallonetti@energycenter.org
}

check for updates

Citation: Pallonetti, N.; Williams, B.D..H.. Refining Estimates of Fuel-Cycle Greenhouse-Gas Emission Reductions Associated with California's Clean Vehicle Rebate Project with Program Data and Other Case-Specific Inputs. Energies 2021, 14, 4640. https://doi.org/10.3390/en 14154640

Academic Editor: Valery Vodovozov

Received: 12 July 2021

Accepted: 28 July 2021

Published: 30 July 2021

Publisher's Note: MDPI stays neutral with regard to jurisdictional claims in published maps and institutional affiliations.

Copyright: (c) 2021 by the authors. Licensee MDPI, Basel, Switzerland. This article is an open access article distributed under the terms and conditions of the Creative Commons Attribution (CC BY) license (https:/ / creativecommons.org/licenses/by/ $4.0 /)$.

\begin{abstract}
This work refines and updates estimates of the fuel-cycle greenhouse-gas (GHG) emission impacts of electric vehicles (EVs) rebated in California. Emissions are estimated using disaggregated data from the start of the rebate program through August $2018(\mathrm{~N}=269,902$ participants) and factors that characterize fuel use and fuel life-cycle carbon intensity. GHG reductions are calculated for the first year of vehicle operation and subsequently scaled to reflect various operational timeframes. GHG reduction estimates over the first year of vehicle ownership total approximately 855 thousand metric tons of $\mathrm{CO}_{2}$-equivalent emissions, or 3.2 tons per vehicle. For nonfleet individuals, $54 \%$ of reductions are associated with "Rebate-Essential" participants who were most highly influenced by the rebate to purchase/lease. Comparing the estimated warranty-life benefit of 7.9 million tons of GHG reductions to USD 603 million in corresponding rebates results in USD 76 of state incentives per metric ton reduced over the first 100,000/150,000 miles of rebated vehicle use. Uncertainty in estimates presents opportunities for further refinement using additional participant-specific, timevariant, or otherwise detailed inputs. Nevertheless, the contributions of this work increased average first-year GHG reductions per vehicle by $35-45 \%$ compared to previous work, demonstrating that use of program-derived data can enhance the understanding of EV impacts.
\end{abstract}

Keywords: electric vehicle; EV; carbon footprint; emissions

\section{Introduction}

\subsection{Motivation}

A primary motivation for federal, state, and regional investment in electric-vehicle (EV) commercialization and wide-spread adoption is the need to reduce greenhouse-gas (GHG) and other emissions from the light-duty-vehicle (LDV) sector, which is a major contributor to U.S. carbon emissions. The California Air Resources Board's (CARB's) Clean Vehicle Rebate Project (CVRP) provides cash rebates to California consumers for the purchase or lease of eligible light-duty electric vehicles (and other vehicles not examined here such as zero-emission motorcycles). It represents an investment exceeding one-half of a billion dollars over the life of the project, which began in 2010, through August 2018.

\subsection{Previous Related Work}

As highlighted in multiple literature reviews [1-3] many studies have used life-cycle assessments (LCAs) to evaluate the environmental effects of EV operation and how those compare to internal combustion engine vehicles. These studies often use one or more illustrative EVs or average EV characterizations as the basis of the analysis [2]. Some EV LCAs use their results to make forward-looking projections to estimate the potential of EVs' role in reaching climate goals over the decades to come [4-9]. Others have assessed the cumulative impact of fleetwide EV adoption that has occurred to help understand expected emission reduction progress from EVs acquired to date [10]. 
As discussed in [3] the reviewed literature has generated a wide range of results due to differing study parameters such as goals, scopes, models, scales, timespans, and datasets used. This underscores the need for context-specific analyses to understand EV impacts for a given vehicle population. However, the theme found across studies is that EVs generally emit fewer life-cycle GHG emissions than internal combustion engine vehicles. Most results have found comparatively higher emissions from EVs in the production phase-which is a relatively small portion of overall LCA emissions-which are then more than offset by lower in-use emissions.

Prior comparable estimates of fuel-cycle GHG emission reductions associated with CVRP, developed in support of CARB's fiscal year 2017-18 low-carbon transportation Funding Plan process [11], were based upon an average LDV fuel economy value for California in 2017, derived from the EMFAC model [12]. This fuel economy was converted into two emissions-per-mile factors using fuel carbon intensities [13] and energy-efficiency ratios [14] from the Low Carbon Fuel Standard (LCFS), one each to represent the fuelspecific life-cycle emissions rate from a baseline new gasoline vehicle and a rebated batteryelectric vehicle (BEV). These were combined into a third emissions-per-mile factor for a rebated plug-in hybrid electric vehicle (PHEV), presumably based upon an assumed proportion of electric $(40 \%)$ and gasoline $(60 \%)$ operation [15]. The difference between baseline and rebated emission factors was then multiplied by annual vehicle miles traveled (VMT) — one value each for PHEVs and BEVs — and scaled up in proportion to the number of rebates for each. This approach was applied to a range of light-duty-vehicle programs. It was designed to generate a conservative estimate of programs' current-year impacts, with a plan to revise "... as new data becomes available and methodologies are refined" [11].

\subsection{Contribution and Overview}

The work described herein supplements previous studies that have assessed the cumulative emissions impact of fleetwide EV adoption that has occurred to date in the United States. This effort fills a gap in existing fuel-cycle (well-to-wheels) EV emissions literature by providing a context-specific analysis of a large number $(\mathrm{N}=269,902)$ of rebated vehicles in California. It builds off the prior comparable estimates of emission reductions associated with CVRP described above with the goal of improving our understanding of: (a) what impact the use of disaggregated, vehicle-specific data has on fuel-cycle GHG savings estimates in California (as opposed to using an illustrative model or average vehicle characterizations), and (b) the emissions benefits associated with and attributable to the United States' largest EV rebate program. With a focus on incorporating more tailored data and increasing the detail of the methods employed in estimating the GHG impacts of CVRP specifically, it expands upon prior efforts to quantify the emissions impact of the project in six major ways:

1. It extends the perspective from annual reporting towards a "life-of-project" view, examining emission reductions from CVRP's inception in 2010 through the end of August 2018. (The end of the date range reflects the most recent data available for this use at the time of the analysis; subsequent work in progress will incorporate more recent data and select other features described in Section 4.2.)

2. It incorporates project-derived and/or case-specific data. Specifically, it employs model- and model-year-specific fuel consumption rate values corresponding to the nearly 270,000 vehicles rebated, as well as model-specific electric-VMT values corresponding to over 100,000 rebated PHEVs. California-sales-weighted average fuel consumption rate values were created for each model year of baseline gasoline vehicles for comparison.

3. It includes an initial quantification of GHG savings from rebated fuel-cell electric vehicles (FCEVs).

4. It assesses how emissions vary by rebate type and consumer type.

5. It analyzes the sensitivity of the results to variations in individual input values. 
6. It uses metrics of "Rebate Essentiality" [16,17] from nearly 40,000 corresponding survey respondents to highlight those emissions savings produced by consumers most highly influenced by the rebate to acquire an EV.

As such, the work aims to provide a more project-specific, detailed, and increasingly accurate estimate of the project's emission impacts.

These contributions increased average first-year GHG reductions per vehicle by $35-45 \%$ compared to previous work [11], demonstrating that use of program-derived data can significantly enhance the understanding of the EV impacts. Comparing the estimated warranty-life benefit of 7.9 million total metric tons of reduced GHG emissions to the USD 603 million in corresponding rebates results in an estimate of roughly USD 76 of state incentives per metric ton reduced over the first 100,000/150,000 miles of rebated vehicle use, or about $13 \mathrm{~kg}$ of $\mathrm{CO}_{2}$-equivalent emissions reduced over that period per incentive dollar invested. Uncertainty in such estimates, which are heavily influenced by the generally conservative assumptions in this study, presents opportunities for further refinement using additional participant-specific, time-variant, or otherwise detailed inputs.

The remainder of the report is organized as follows. Section 2 characterizes the data utilized and describes the approach taken to estimate emission reductions using factors characterizing rebated- and baseline-vehicle fuel consumption rates, VMT, electric VMT, and the life-cycle carbon intensity of fuels. Section 3 summarizes the resulting estimates and sensitivity analysis. Reductions attributable to CVRP-rebated PHEVs, rangeextended BEVs (BEVx vehicles), BEVs, and FCEVs over the first year of vehicle ownership are estimated per vehicle and in aggregate. These savings are then scaled up to reflect the battery warranty lifespan. A subset of emission reductions is then highlighted to reflect "Rebate-Essential" participants who were most highly influenced by the rebate to purchase/lease their vehicles. Sensitivity analyses are presented, indicating opportunities for further refinement using participant-specific inputs. Further, bounding estimates are created and other operational timeframes are explored. Section 4 discusses the results, their interpretation, and next steps-including opportunities to incorporate more project-specific information and conservatisms to address. Section 5 presents summarizing thoughts.

\section{Materials and Methods}

\subsection{Data Summary}

\subsubsection{Application Data}

The rebated vehicle dataset from which emissions associated with the project are estimated is comprised of vehicles with issued (paid) rebates or approved applications (check forthcoming) over the life of the project through August 2018. The dataset includes individual and fleet (governmental, business, and nonprofit) consumer types and PHEV, BEVx, $\mathrm{BEV}$, and FCEV drivetrain categories (technology types). Individual consumers include two rebate types: Standard Rebates and Increased Rebates for Low-/Moderate-Income (LMI) Consumers (the latter have been available since 29 March 2016) [18]. Zero-emission motorcycles and other technology types totaled $<1 \%$ of all records and were removed for simplicity. The final dataset included 269,902 applications totaling USD 603,314,214 in rebates. Vehicle purchase/lease dates spanned 11 March 2009-31 August 2018 and CVRP application-received dates spanned 18 March 2010-31 August 2018.

\subsubsection{Survey Data}

CVRP invites individual (i.e., non-fleet) applicants that have been approved to receive a rebate to fill out a voluntary Consumer Survey. Survey responses are used to classify fractions of emission reductions as Rebate Essential (from consumers most highly influenced by the rebate to adopt, see Section 2.2.3). The survey has undergone several modifications since the beginning of the project, dividing it into three "editions" (Table 1). Responses from all technology types were used, though it should be noted that FCEV consumers were invited to participate in the survey beginning with the third edition (with previous FCEV applicants from the start of the project invited to respond to the survey at that time). 
Though analyzed separately, BEVx is grouped with BEV for all survey assumptions where needed, as BEVx consumers are expected to be more akin to BEV consumers than PHEV consumers. This also follows the project's approach to providing BEVx vehicles equivalent incentives to BEVs.

Table 1. Consumer Survey Dates.

\begin{tabular}{|c|c|c|c|c|c|}
\hline & \multirow{2}{*}{ 2013-15 Edition } & \multirow{2}{*}{ 2015-16 Edition } & \multicolumn{2}{|c|}{ 2016-17 Edition } & \multirow{2}{*}{ Total } \\
\hline & & & PEVs & FCEVs & \\
\hline Responses & $n=19,361$ & $n=11,577$ & $n=8957$ & $n=410$ & $n=40,305$ \\
\hline $\begin{array}{l}\text { Weighted to } \\
\text { Represent }\end{array}$ & $\mathrm{N}=91,081$ & $\mathrm{~N}=45,694$ & $\mathrm{~N}=46,838$ & $\mathrm{~N}=1749$ & $\mathrm{~N}=185,362$ \\
\hline $\begin{array}{c}\text { Vehicle } \\
\text { Purchase/Leases }\end{array}$ & $\begin{array}{c}\text { September } \\
\text { 2012-May } 2015\end{array}$ & April 2015-May 2016 & May 2016-May 2017 & $\begin{array}{c}\text { December } \\
\text { 2010-May } 2017\end{array}$ & $\begin{array}{l}\text { PEVs: September } \\
\text { 2012-May } 2017 \\
\text { FCEVs: December } \\
\text { 2010-May } 2017\end{array}$ \\
\hline $\begin{array}{l}\text { Additional } \\
\text { Participants } \\
\text { Assigned }\end{array}$ & $\mathrm{N}=11,916$ & $N=2052$ & $\mathrm{~N}=59,820$ & $N=2669$ & $\mathrm{~N}=76,457$ \\
\hline $\begin{array}{l}\text { Total Participants } \\
\text { Assigned }\end{array}$ & $\mathrm{N}=102,997$ & $\mathrm{~N}=47,746$ & $\mathrm{~N}=106,658$ & $\mathrm{~N}=4418$ & $\mathrm{~N}=261,819$ \\
\hline $\begin{array}{c}\text { Assigned } \\
\text { Purchase/Lease } \\
\text { Dates }\end{array}$ & $\begin{array}{c}\text { March } \\
\text { 2009-May } 2015\end{array}$ & April 2015-May 2016 & $\begin{array}{c}\text { May } \\
\text { 2016-August } 2018\end{array}$ & $\begin{array}{c}\text { June } \\
\text { 2010-August } 2018\end{array}$ & $\begin{array}{c}\text { March } \\
\text { 2009-August } 2018\end{array}$ \\
\hline
\end{tabular}

Survey responses are weighted using the raking method (iterative proportional fitting) to make the survey responses more representative of the program populations during each period. The weighting was performed along the dimensions of technology type, vehicle model, purchase vs. lease, and county of residence. Finally, non-respondents that fall within a project era that is not represented by a survey are assigned to the survey edition that they are "nearest to" based on purchase/lease date (e.g., early project participants that are not represented by the first survey were assigned to the first survey, and recent project participants that are not represented by the latest survey were assigned to the latest survey). All FCEV consumers are assigned to the most recent survey edition, as this was the first edition to which this group was invited. The editions of the survey and their assigned participants are described in Table 1.

\subsubsection{Vehicle Registration Data}

The baseline-vehicle sales-weighted fuel consumption rate values (Table 2, row 4) were calculated using registration data licensed from IHS Markit. The data include monthly new gasoline and electric vehicle registrations in California from March 2010 through July 2018.

\subsection{Methods and Inputs}

GHG reductions associated with the project are calculated by comparing estimates of on-road emissions from each vehicle that was rebated to a baseline vehicle assumed to have been used had the rebated vehicle not been acquired. These reductions are assessed at two levels: (1) savings associated with all rebated project participants, or "rebated reductions," and (2) savings associated with consumers most highly influenced by the rebate to purchase/lease an EV, or "Rebate-Essential reductions."

The approach for estimating emissions is described next, inputs and sources are detailed further in Table 2, and sensitivity testing is described in Section 3.2. Only lightduty vehicles are included throughout.

\subsubsection{Rebated Emission Reductions: Approach}

Annualizing emissions for simplicity, rebated reductions (in units of metric tons of $\mathrm{CO}_{2}$-equivalent emissions, or $\mathrm{tCO}_{2} \mathrm{e}$ ) are calculated by summing for each rebate the 
difference between estimates of the emissions avoided (baseline vehicle, $E_{\text {baseline}}$ ) and the emissions produced (rebated vehicle, $E_{\text {rebated }}$ ) over a year of operation:

$$
\text { Rebated reductions }=\sum_{i}\left(E_{i, \text { baseline }}-E_{i, \text { rebated }}\right)
$$

where:

$i=$ each individual baseline and rebated vehicle pair;

$E=$ annual emissions.

Following [11], the baseline vehicle is assumed to be a new gasoline vehicle of the same model year (MY) as the rebated vehicle.

For each baseline vehicle:

$$
E_{i \text {, baseline }}=C I_{\text {gasoline }} \times F C_{\text {gasoline }}(M Y) \times V M T_{\text {gasoline }}(c, d, r)
$$

where:

$E=$ emissions avoided annually;

$i=$ individual vehicle;

baseline $=$ vehicle that would have been used had the rebated vehicle not been acquired;

$C I_{\text {gasoline }}=$ carbon intensity of gasoline in units of life-cycle $\mathrm{CO}_{2}$ e per gallon;

$F C_{\text {gasoline }}=$ gasoline consumption rate in units of gallons per mile, which varies by model year (MY) of the paired rebated vehicle;

$V M T_{\text {gasoline }}=$ vehicle miles traveled annually, which varies by consumer type $(c)$ and the paired rebated vehicle's drivetrain category $(d)$, and, for BEVs only, range subcategory $(r)$.

For each rebated vehicle:

$$
E_{i, \text { rebated }}=\sum_{f}\left(C I_{f} \times F C_{f}(m, M Y) \times\left[V M T_{f}(c, d, r) \times P_{f}(m, M Y)\right]\right)
$$

where:

$E_{i, \text { rebated }}=$ emissions produced annually by each individual rebated vehicle;

$f=$ fuel used by rebated vehicle \{gasoline, electricity, hydrogen\};

$\mathrm{CI}_{f}=$ carbon intensity of fuel $f$ in units of life-cycle $\mathrm{CO}_{2}$ e per unit of fuel;

$F C_{f}=$ fuel consumption rate in units of gal, $\mathrm{kWh}$, or $\mathrm{kg}$ of fuel $f$ per mile, which varies by model $(m)$ and model year $(M Y)$;

$V M T_{f}=$ vehicle miles traveled annually on fuel $f$, which varies by consumer type $(c)$, drivetrain category $(d)$, and, for BEVs only, range subcategory $(r)$;

$P_{f}=$ percent of miles traveled on fuel $f$, which varies by $m$ and $M Y$ for PHEVs.

Carbon intensity, fuel consumption rate, and vehicle miles traveled are described further next.

Carbon intensity of fuels. Consistent with [11], this work uses statewide average carbon intensity (CI) values from California's LCFS program regulations $[14,19,20]$. These values represent the amount of $\mathrm{CO}_{2}$-equivalent emissions $\left(\mathrm{CO}_{2} \mathrm{e}\right)$ emitted during the lifecycle of each fuel, accounting for upstream and combustion emissions. This approach neither accounts for changes to the CI of fuel sources over time nor weighs in on the issue of assigning marginal/induced grid emissions (which is a shorter-term perspective on assigning emissions to added electrical load that would include assessing which power plants can scale in response to demand and the time of day in which load is added). 
Table 2. Input Values and Sources.

\begin{tabular}{|c|c|c|}
\hline Characteristic & Rebated Vehicle & Baseline Vehicle \\
\hline $\begin{array}{l}\text { Model year } \\
\text { Source: rebate application }\end{array}$ & $\begin{array}{l}\text { Individuals }=\{\text { MY2009 } \ldots \text { MY2019 }\} \\
\text { Fleets }=\{\text { MY2009 . MY2018 }\}\end{array}$ & Same as paired rebated vehicle, consistent with [11] \\
\hline $\begin{array}{l}\text { Drivetrain category } \\
\text { Source: rebate application }\end{array}$ & $\{$ PHEV, BEVx, BEV, FCEV $\}$ & $\{$ Gasoline $\}$, consistent with [11] \\
\hline $\begin{array}{l}\text { Fuel life-cycle carbon intensity } \\
\text { Source: calculations using data from [14] or [19] }\end{array}$ & $\begin{array}{l}\left\{\text { Gasoline }=11,518 \mathrm{~g} \mathrm{CO}_{2} \mathrm{e} / \text { gal }\right. \\
\text { Electricity }=379 \mathrm{~g} \mathrm{CO}_{2} \mathrm{e} / \mathrm{kWh} \\
\left.\text { Hydrogen }=13,393 \mathrm{~g} \mathrm{CO}_{2} \mathrm{e} / \mathrm{kg}\right\}\end{array}$ & $\left\{11,518 \mathrm{~g} \mathrm{CO}_{2} \mathrm{e} / \mathrm{gal}\right\}$ \\
\hline $\begin{array}{l}\text { Annual vehicle miles traveled (VMT) } \\
\text { Sources: [22,23] for individuals; calculations using data from } \\
\text { [22-24] for fleets (see Appendix B) }\end{array}$ & $\begin{array}{l}\text { Individuals }=\{\mathrm{PHEV}=13,472 ; \\
\mathrm{BEVx}, \text { Short range BEV }(<200 \mathrm{mi} .)=11,366 ; \\
\text { Long range } \mathrm{BEV}(\geq 200 \mathrm{mi} .)=13,456 ; \\
\mathrm{FCEV}=12,445\} \\
\text { Fleets }=\{\mathrm{PHEV}=9207 ; \\
\mathrm{BEVx}, \text { Short range BEV }(<200 \mathrm{mi} .)=7768 ; \\
\text { Long range BEV }(\geq 200 \mathrm{mi} .)=9196 ; \\
\text { FCEV }=8505\}\end{array}$ & $\begin{array}{l}\text { Same as paired rebated vehicle, } \\
\text { consistent with [11] }\end{array}$ \\
\hline $\begin{array}{l}\text { Lifetime VMT } \\
\text { Sources: [25,26] for PHEV; [27] for other drivetrain categories }\end{array}$ & $\begin{array}{l}\text { Individuals \& Fleets }=\{\mathrm{PHEV}=150,000 \\
\mathrm{BEV}, \text { Short range BEV, Long range BEV, FCEV }=100,000\}\end{array}$ & $\begin{array}{l}\text { Same as paired rebated vehicle, } \\
\text { consistent with [11] }\end{array}$ \\
\hline $\begin{array}{l}\text { PHEV electric-VMT percentage } \\
\text { Sources: }[22,32] \text { or calculations using data from }[21,22,32-36]\end{array}$ & $\begin{array}{l}\text { Model-/MY-specific percentage from literature (when } \\
\text { available) or calculated as a function of electric range (see } \\
\text { Appendix C) }\end{array}$ & n.a. \\
\hline BEVx (BMW i3 REx) electric-VMT percentageSource: [32] & $\{92 \%$ electric fuel $\}$ & n.a. \\
\hline $\begin{array}{l}\text { Rebate Essentiality } \\
\text { Source: Consumer Survey data (unweighted direct responses } \\
\text { and weighted averages) }\end{array}$ & $\begin{array}{l}\{1,0\} \text { for those with survey responses; for others, used the } \\
\text { average by technology type for the corresponding project } \\
\text { era/survey edition, ranging } 41.3-66.9 \%\end{array}$ & $\begin{array}{l}\text { [applies to case as a whole; emission reductions counted are } \\
\text { proportional to Rebate Essentiality value (e.g., case excluded if } \\
\text { not Rebate Essential)] }\end{array}$ \\
\hline
\end{tabular}


Fuel consumption rate. Rebated vehicle fuel consumption rates are determined on a model- and model-year-specific basis using EPA data [21]. Following [11], the baseline vehicle is assumed to be a new gasoline vehicle of the same model year as the rebated vehicle. However, this study utilizes California-sales-weighted average fuel consumption rates created for baseline vehicles, as described in Table 2 and detailed in Appendix A. These are different, more context-specific values than those calculated from EMFAC forecasts and used in [11]. The EPA data provided in units of fuel economy (e.g., miles per gallon) are converted to fuel consumption rates (e.g., gallons per mile) for analysis.

Vehicle miles traveled. Annual VMT estimates for individuals come from surveys of EV drivers in California conducted by the PH\&EV Research Center at UC Davis [22,23]. These estimates vary by the rebated vehicle technology type and, for BEVs, the range subcategory of the model (long or short). Fleet VMT is based on the U.S. General Services Administration's Federal Fleet Report [24] and adjusted to reflect the variations by technology type found in individuals, as detailed in Table 2 and described in Appendix B. For PHEVs and BEVx vehicles, which use both electric and gasoline fuels, a model-specific electric-VMT percentage is used to assign fractions of total travel to electricity (see Table 2 and Appendix $C$ for further detail). For example, emissions from $92 \%$ of travel for a rebated BMW i3 REx are calculated using the CI of electric fuel and the remainder is calculated using the $\mathrm{CI}$ of gasoline.

\subsubsection{Rebated Emission Reductions: Operation Lifetime Assumption}

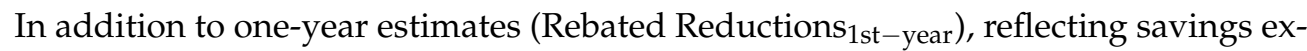
pected during the first year of vehicle operation, rebated reductions are reported in terms

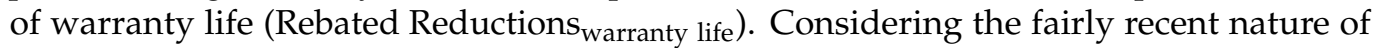
their widespread availability and accelerated adoption, the average length of an EV's useful life is not yet clear. It can be assumed, however, that EVs are likely to last at least as long as their warranties. Therefore, lifetime emission savings are quantified over the mileage period associated with the vehicle's battery warranties. The warranty lifetime assumption varies by technology type and is based on the 150,000-mile battery warranty for PHEVs required by California's Zero-Emission Vehicle Standards $[25,26]$ and the most common battery warranty of 100,000 miles [27] for other EVs. While BEVx batteries are covered for 150,000 miles under California's Standards, BEVx vehicles are analyzed over the 100,000-mile period of other EVs here as a conservatism and to align more closely with the total miles expected to be driven over the 10-year warranty period associated with the 150,000 warranty miles.

Both perspectives are useful for different reasons: First-year GHG savings better illustrate the variations across vehicle types and consumer types that result from differences in annual mileage estimates or carbon intensity of fuels. They also provide the reader a mechanism, albeit a slightly rough one, for scaling up emissions savings to a variety of timescales of interest (e.g., for comparison across programs or to compare different assumptions of vehicle ownership, use, and/or lifetime capacity). The warranty-life reductions, on the other hand, can be viewed as reductions achieved over the time period the vehicles should very reasonably be expected to last (which is, in turn, a conservative proxy for the actual lifetime capacity of the vehicles to provide benefits).

Consistent with [11], estimates are simplified here by multiplying first-year emission reductions to represent lifetime results, rather than modeling each year with timevariant factors:

Rebated Reductions ${ }_{i \text {, warranty life }}=$ Rebated Reductions $_{i, \text { 1st-year }} \times\left(\frac{\text { Warranty Miles }(d)}{V M T(c, d, r)}\right)$.

\subsubsection{Rebate-Essential Emission Reductions}

One difficulty in estimating emission reductions directly attributable to the project is identifying EV sales that would not have happened without the rebate. To provide a more comprehensive picture of benefits directly attributable to CVRP, GHG reductions associated 
with consumers most highly influenced by the rebate to acquire an EV are calculated separately. As described in previous work [16,17], the CVRP Consumer Survey (see Section 2.1.2) provides project-specific insights into the influence of the project. Those who answer "No" to the question, "Would you have purchased your [rebated EV model] without the CVRP rebate?" are categorized as "Rebate-Essential"-i.e., not free-riders. Accordingly, responses to this question were used to direct focus toward emission reductions enabled by and directly attributable to the project. Specifically, if a participant was known to be Rebate-Essential, their emission reductions are included. If a participant was known to not be Rebate-Essential, their emission reductions are not included. If it was unknown whether a participant was Rebate-Essential, a fraction of their emission reductions are included equal to the percentage of Rebate Essentiality among their cohort (i.e., by technology type and assigned survey edition, see Appendix D). Since only individual (i.e., non-fleet) consumers were invited to respond to the survey, fleets are not analyzed for Rebate Essentiality or Rebate-Essential reductions.

\section{Results}

\subsection{GHG Emission Reduction Estimates}

Total GHG emission reductions achieved by the 269,902 rebated PHEVs, BEVx vehicles, BEVs, and FCEVs over the first year of vehicle ownership are estimated to be approximately 855,000 metric tons of $\mathrm{CO}_{2}$-equivalent emissions $\left(\mathrm{tCO}_{2} \mathrm{e}\right)$. This increases to 7.9 million $\mathrm{tCO}_{2} \mathrm{e}$ when scaled up to represent a 100,000-/150,000-mile warranty life. Approximately $53-54 \%$ of the reductions from individuals are associated with Rebate-Essential participants. Per-vehicle reductions estimates average $3.2 \mathrm{tCO}_{2} \mathrm{e}$ over the first year of ownership and $29 \mathrm{tCO}_{2} \mathrm{e}$ over the warranty life. Per-vehicle reductions by technology and rebate type are detailed in Figures 1 and 2 below. These results are explored further in Section 3.2 and discussed in Section 4.

Another noteworthy observation relates to cost-effectiveness: this analysis indicates each ton of $\mathrm{CO}_{2}$ e saved over the 100,000-/150,000-mile warranty period is associated with approximately USD 76 in rebates, or about $13 \mathrm{~kg}$ of $\mathrm{CO}_{2} \mathrm{e}$ is saved per incentive dollar. It should be noted that these findings are subject to the limitations discussed in Section 4.2.

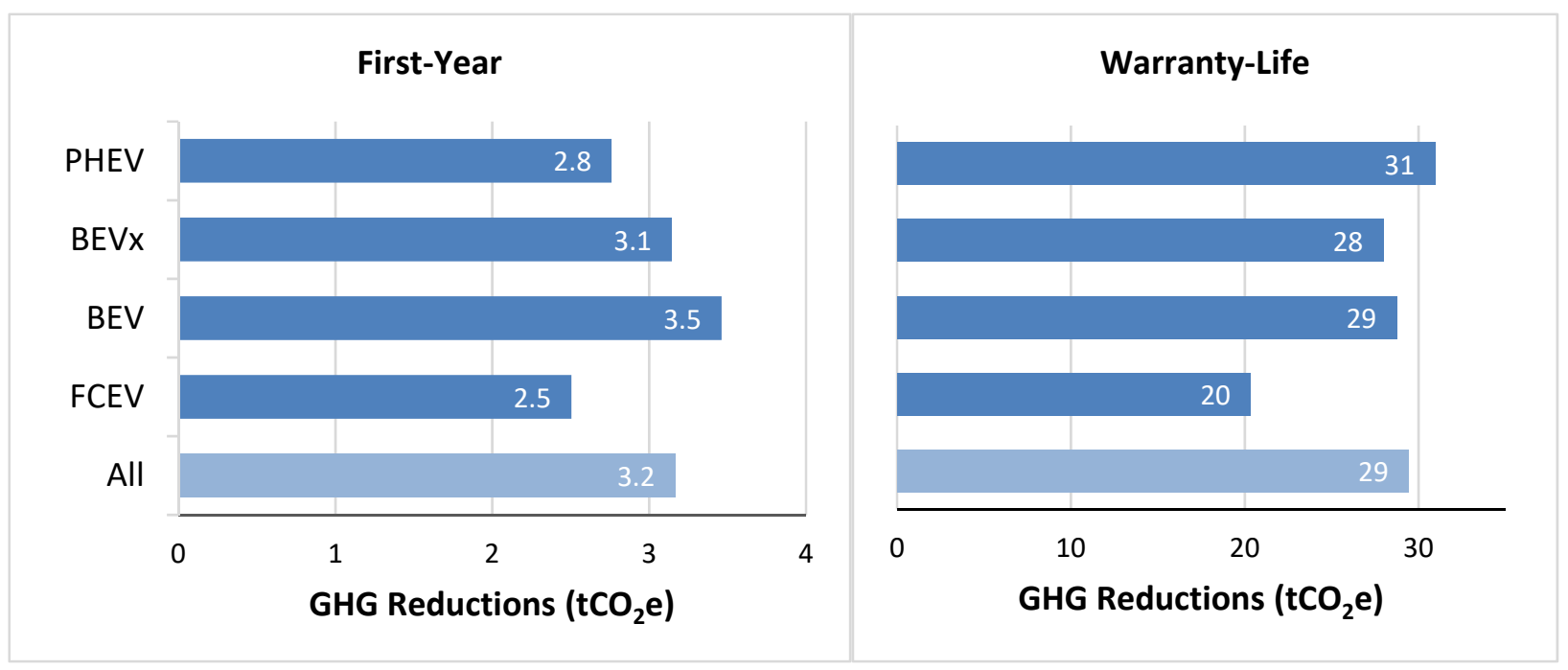

Figure 1. Per-Vehicle GHG Reduction Estimates by Technology Type and Quantification Period. 


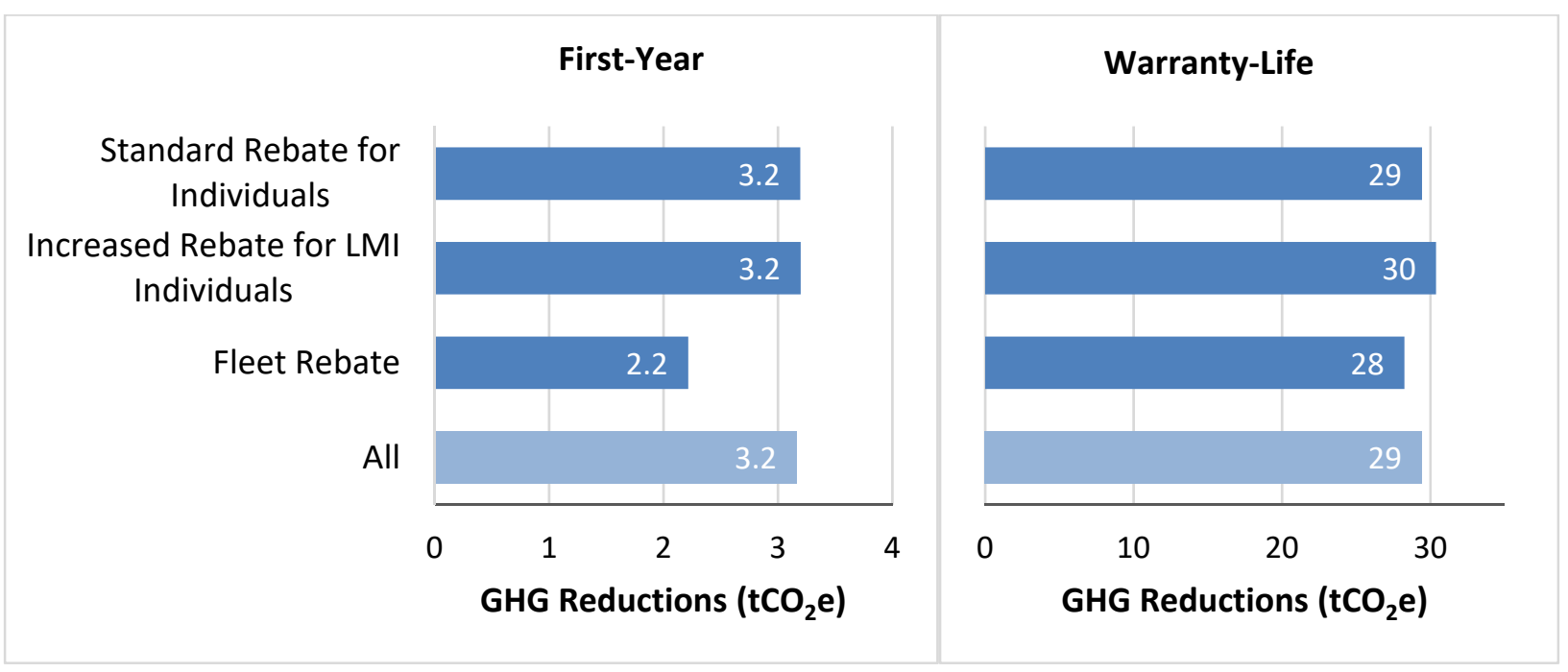

Figure 2. Per-Vehicle GHG Reduction Estimates by Rebate Type and Quantification Period.

\subsection{GHG Sensitivity Analysis}

Sensitivity analyses were conducted to assess the impact of the uncertainty in several individual input values on emission reductions. As described in the subsections below, the literature about related topics helped inform value ranges for sensitivity tests. The isolated effects of these tests on the total first-year GHG reduction estimates range from $-29 \%$ to $+24 \%$ for individuals and $-32 \%$ to $+69 \%$ for fleets. Further, bounding estimates are created for several inputs and various operational timeframes are explored.

\subsubsection{Sensitivity to Baseline-Vehicle Fuel Consumption Rates}

GHG emission reduction estimates were sensitive to changes in the baseline fleet fuel consumption rates. The baseline fleet fuel consumption rates are comprised of Californiasales-weighted averages of EPA-adjusted consumption rates for the 30 top-selling new gasoline models in each model year (MYs 2011-2018). Sales data were not available for MYs 2009-2010, so EPA-adjusted U.S.-production-weighted averages from [31] were used for these model years. Car-only averages were used because they were found to represent average California fuel consumption rates more closely than car-and-truck averages for MYs 2011-2017 (see Appendix A for further detail). The sensitivity test changed these to the U.S.-production-weighted car-and-truck averages [31,37]. This covers the unlikely scenario that larger cars and trucks would have been purchased without CVRP (which generally rebated cars of modest size during the period examined). The U.S. car-and-truck averages range $11-15 \%$ less fuel-efficient than the primary assumptions and resulted in a $24 \%$ increase in the first-year emission reduction estimates for both individuals and fleets.

Due to the lack of a comparable source for a high fuel-efficiency average, the sensitivity test used the magnitude of the largest deviation from the primary assumptions in the lowefficiency scenario (15\%). This resulted in a decrease in the first-year emission reduction estimates of $21 \%$ for both individuals and fleets. However, it is possible that without the rebate many participants would have tended toward purchasing conventional hybrid vehicles that are more than $15 \%$ more fuel efficient than the assumed baseline vehicle. Accordingly, the authors explored an extreme high-efficiency bounding scenario using the fuel consumption rate of the most fuel-efficient non-EV for each model year. These were based on fuel economy values ranging from 46-58 MPG and resulted in a 76\% decrease in emission reductions from the primary estimate for both individuals and fleets.

\subsubsection{Sensitivity to Annual Vehicle Miles Traveled}

The emission reduction estimates were also sensitive to changes in annual VMT, which were tested differently for individuals and fleets since primary VMT assumptions differ by 
consumer type. For individuals, a low-VMT scenario was tested by assigning the lowest annual VMT for any PHEV model found in the literature (11,122 miles) [38] to PHEVs and assigning the lowest VMT for any BEV model (7916 miles) [32] to all other technology types. These low-VMT values range $17-41 \%$ lower than the primary assumptions and decreased the first-year GHG reduction estimate for individuals by $29 \%$. In the high-VMT scenario for individuals, the highest VMT for any PHEV model found in the literature $(15,283$ miles) [32] was used for PHEVs, long-range BEVs, and FCEVs; and the highest VMT for any BEV model in the literature (13,494 miles) [32] was used for short-range BEVs and BEVx vehicles. These high-VMT values range from 13-23\% higher than the VMT assumed in the analysis and increased the estimated GHG savings by $16 \%$.

Because primary VMT assumptions are lower for fleets than individuals, a low scenario for fleets was tested by decreasing VMT for each technology type by the same magnitude as the test for individuals (17-41\%). This decreased the first-year GHGs saved from fleet vehicles by $32 \%$. To account for the uncertainty related to CA fleet VMT, a high-upside test used the same high VMT inputs for individuals (13,494 and 15,283 miles), which increased the fleet GHG savings by $69 \%$.

\subsubsection{Sensitivity to Electric-VMT Percentage}

The sensitivity of the estimated GHG reductions to assumptions about PHEV and BEVx electric-VMT percentages (i.e., the portion of travel in all electric mode) were also evaluated. Changing the assumption to the lowest value for any PHEV model found in the literature (12\%) [22] for all PHEV models decreased the total first-year GHG emission reductions estimate by $10 \%$ for individuals and $6 \%$ for fleets. Shifting the assumption to the highest value for any PHEV model found in the literature (74.5\%) [33] increased the first-year GHG reduction estimate by $6 \%$ for individuals and $5 \%$ for fleets.

Shifting the BEVx (BMW i3 REx) electric-VMT percentage assumption from $92 \%$, as found in the literature [32], to 100\% electric increased the total GHG emission reductions estimate by $0.1 \%$ for both individuals and fleets. Decreasing the primary assumption by the same magnitude ( 8 percentage points, to $84 \%$ ) decreased the reduction estimate by $0.1 \%$ for individuals and $0.2 \%$ for fleets.

\subsubsection{Sensitivity to Carbon Intensity of Fuels}

The sensitivity of GHG reductions to fuel carbon intensities was tested by using varying inputs from the LCFS. This program has steadily decreasing annual benchmarks for gasoline CI based on a 2010 baseline [19], annual reports about changes to the CI of electricity used as a transportation fuel [20], and reports about the CI of other alternative transportation fuels every few years [14,19].

Sensitivity to the CI of gasoline was tested by updating the value from the LCFS regulation's [19] CI baseline from 2010 (consistent with [11]) to the regulation's CI benchmark for 2019 (10,799 $\left.\mathrm{g} \mathrm{CO}_{2} \mathrm{e} / \mathrm{gal}\right)$. This decreased the total first-year emission reductions estimate by $9 \%$ for both individuals and fleets.

Sensitivity to the CI of electricity was tested by updating the value from that reported in the 2015 LCFS regulation [14] based on the grid mix in 2010 (consistent with [11]) to the latest annual CI metric update (299 $\mathrm{g} \mathrm{CO}_{2} \mathrm{e} / \mathrm{kWh}$ ) [20], which uses the 2018 grid mix. This increased the total first-year emission reductions estimate by $8 \%$ for individuals and 9\% for fleets. A high bound for the 2018 grid CI was also tested using a second source: EPA's Emissions and Generation Resource Integrated Database (eGRID2018) [39]. EPA's emission rate for the CAMX subregion (which roughly corresponds to the state of CA) is much lower than the LCFS (226 $\mathrm{g} \mathrm{CO}_{2} \mathrm{e} / \mathrm{kWh}$ ). Using eGRID2018 increased total emission reductions by $15 \%$ for individuals and $17 \%$ for fleets compared to the primary estimates.

The LCFS regulation does not report one overall average hydrogen CI value, but rather a different value for each fuel pathway. The primary input follows recent CARB reporting [40] and assumes SB 1505-compliant gaseous hydrogen reformed on-site at the refueling station from a mix of $67 \%$ North American natural gas and $33 \%$ renewable 
biomethane from landfill gas. The primary CI values are from the 2018 LCFS regulation [19], which includes the highest (and therefore most conservative) hydrogen CI yet reported by the program. (Per personal communication with CARB, this is due to changes in how upstream emissions were evaluated from previous regulations, rather than an increase in the $\mathrm{CI}$ of hydrogen fuel over time.) The low-carbon scenario changed the assumption from a natural gas and biomethane mix to $100 \%$ biomethane $\left(11,938 \mathrm{~g} \mathrm{CO}_{2} \mathrm{e} / \mathrm{kg}\right)$, which increased the total first-year emission reductions estimate by $0.1 \%$ for individuals and $0.2 \%$ for fleets. The high-carbon scenario tested a different LCFS fuel pathway for hydrogen from the 2015 LCFS regulation: central reforming of natural gas with liquefication and regasification steps $\left(18,121 \mathrm{~g} \mathrm{CO}_{2} \mathrm{e} / \mathrm{kg}\right)$. This decreased the total first-year reduction estimate by $0.5 \%$ for individuals and $0.6 \%$ for fleets.

To assess the extent that electric grid and hydrogen improvements can increase emission reductions achievable from these vehicles, an extreme bounding scenario was calculated with $100 \%$ carbon-free electricity and hydrogen. This resulted in an increase of $38 \%$ for individuals and $44 \%$ for fleets compared to the primary first-year emission reduction estimates.

\subsubsection{Sensitivity to Rebate Essentiality}

Sensitivity of the Rebate-Essential reductions estimates for individuals to the Rebate Essentiality percentages was tested by adding and subtracting the margin of error for these percentages. The error margin was calculated at the $99 \%$ confidence level based on the sample proportion and sample size of each cohort (by technology type and survey edition). These errors ranged from 1.2 to 2.2 percentage points for PHEVs and BEVs and was equal to 6.0 percentage points for FCEVs. Ten percentage points were added to the margin of error to account for any unknown response bias (resulting from respondents answering questions inaccurately) or selection bias (resulting from the survey being voluntary). Adding and subtracting 11.2-16.0 percentage points from the Rebate Essentiality percentages changed the Rebate-Essential GHG reductions estimate for individuals by $+/-19 \%$.

The isolated effects of the tests described above on the total primary first-year GHG reduction estimates for individuals $(\sim 837,000)$ and fleets $(\sim 18,000)$, excluding bounding estimates and Rebate Essentiality, are presented in Figure 3.

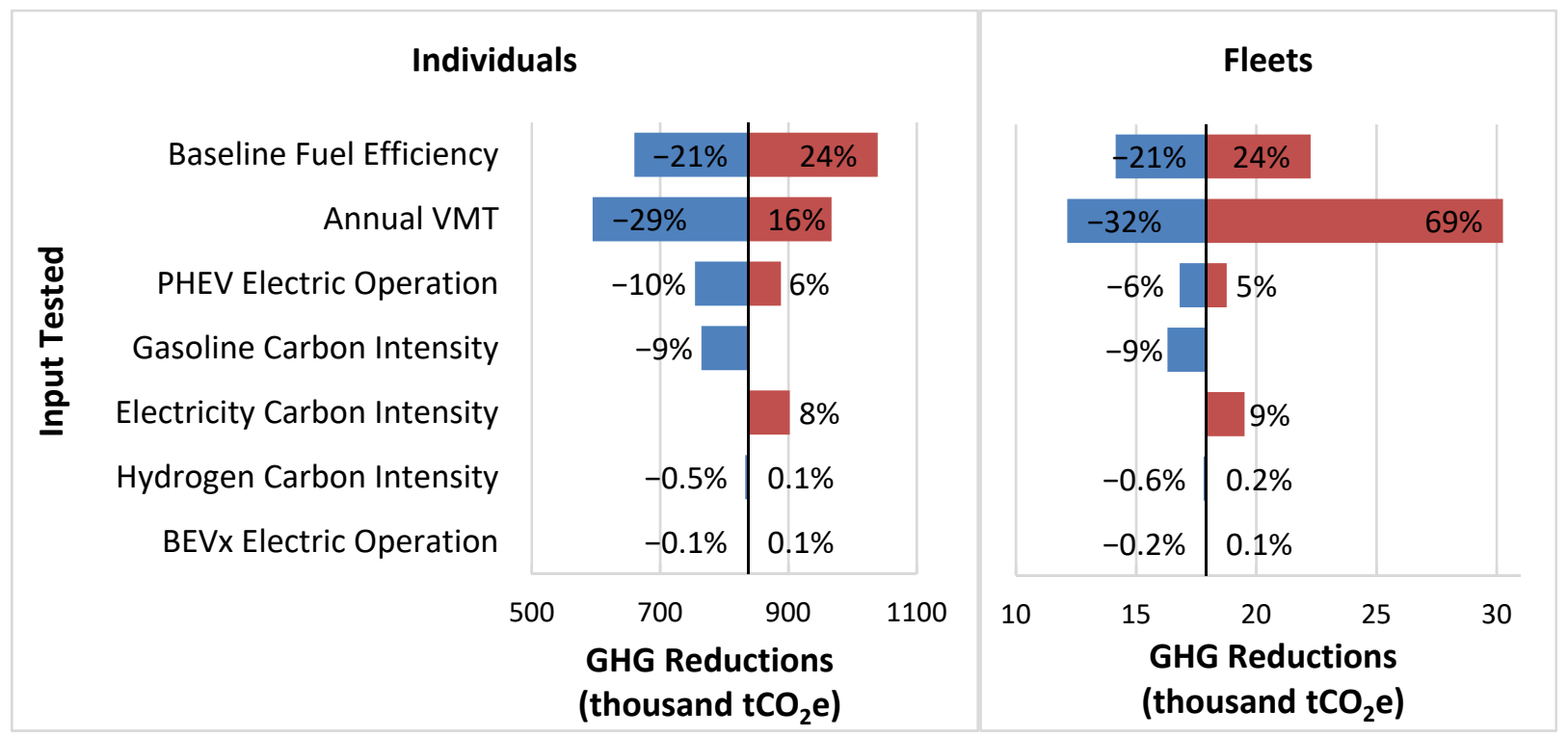

Figure 3. Per-Vehicle GHG Reduction Estimates by Rebate Type and Quantification Period. 


\subsubsection{Operation Lifetime}

The primary estimates in this study consist of first-year reductions and reductions associated with the warranty life of each vehicle. For individuals, which comprise $97 \%$ of the vehicles analyzed, even warranty-life estimates are arguably still a conservative assumption of useful vehicle life for all technology types, depending on a balance of factors. On the one hand, if we assume a consistent annual VMT equal to those used for the firstyear estimates of individuals (as detailed in Table 2), the warranty-life estimates represent 11 years of driving for PHEVs and 7-9 years for other vehicle types. Both are roughly equivalent to the $8 / 10$ warranty years associated with the 100,000-/150,000-mile warranties but represent lower mileage than the expected useful life of the vehicles: predictive modeling by the National Renewable Energy Laboratory [41] indicates that batteries may last 12 to 15 years in moderate climates. Further, vehicles may have an even longer life if batteries are replaced, albeit with additional associated private costs if after the warranty period. On the other hand, vehicle use may decline with time and a modest number of rebated vehicles may leave the state upon change of ownership—which averages 6 years [42]. Lifetime GHG savings could be significantly impacted if vehicles leave the state, as the results in this work are based on the carbon intensity of fuel in California. Additionally, grid emissions are likely to decrease significantly over time as aggressive goals move California and other states toward high levels of renewable energy penetration (discussed more in Section 4.2.3).

Due to the uncertainty around vehicle calendar-year lifetime and the sensitivity of the GHG estimates to VMT, various operation lifetime options and their resulting impacts on the estimates are explored in comparison to the fixed-VMT "warranty life" approach. Savings over these alternate calendar-year lifetimes are estimated by multiplying first-year savings ( 855 thousand $\mathrm{tCO}_{2} \mathrm{e}$ total or $3.2 \mathrm{tCO}_{2} \mathrm{e}$ per vehicle) by the number of lifetime years. A useful "vehicle life" can be conservatively characterized as the average age of vehicles in California, or 11.2 years [43]. These best-guess estimates are supplemented with "project-life" estimates (2.5 years, based upon CVRP terms and conditions) and "ownership-life" estimates (6 years) [42]. Finally, "project-comparison-life" estimates (15 years) are provided in order to better reflect typical expectations about vehicle longevity, the PHEV battery warranty calendar-year life, and National Renewable Energy Laboratory estimates for battery calendar-year life. Project-life estimates also facilitate comparisons with previous work [11] and between CVRP and other programs that make a 15-year vehicle life assumption. As presented in Table 3, the impact of quantifying GHG reductions over these alternate lifetimes compared to the primary warranty-life results ranges from $-73 \%$ to $+61 \%$ in reductions and $-17 \%$ to $+272 \%$ on rebate dollars per ton reduced.

Table 3. Lifetime Assumption Comparison.

\begin{tabular}{|c|c|c|c|}
\hline Lifetime Assumption & $\begin{array}{c}\text { Total Rebated } \\
\text { Reductions } \\
\text { (Thousand } \mathrm{tCO}_{2} \mathrm{e} \text { ) }\end{array}$ & $\begin{array}{l}\text { Per-Vehicle } \\
\text { Reductions } \\
\quad\left(\mathrm{tCO}_{2} \mathrm{e}\right)\end{array}$ & Rebate Dollars Per $\mathrm{tCO}_{2} \mathrm{e}$ \\
\hline Battery Warranty Life & 7944 & 29.4 & USD 76 \\
\hline 2.5-Year Project Life & $\begin{array}{c}2137 \\
(-73 \%)\end{array}$ & $\begin{array}{c}7.9 \\
-73 \%)\end{array}$ & $\begin{array}{l}\text { USD } 282 \\
(+272 \%)\end{array}$ \\
\hline 6-Year Ownership Life & $\begin{array}{c}5128 \\
(-35 \%)\end{array}$ & $\begin{array}{c}19.0 \\
(-35 \%)\end{array}$ & $\begin{array}{l}\text { USD } 118 \\
(+55 \%)\end{array}$ \\
\hline 11.2-Year Vehicle Life & $\begin{array}{c}9573 \\
(+21 \%)\end{array}$ & $\begin{array}{c}35.5 \\
(+21 \%)\end{array}$ & $\begin{array}{l}\text { USD } 63 \\
(-17 \%)\end{array}$ \\
\hline $\begin{array}{l}\text { 15-Year Projectlef } \\
\text { Comparison Life }\end{array}$ & $\begin{array}{l}12,821 \\
(+61 \%)\end{array}$ & $\begin{array}{c}47.5 \\
(+61 \%)\end{array}$ & $\begin{array}{l}\text { USD } 47 \\
(-38 \%)\end{array}$ \\
\hline
\end{tabular}

Note: Battery-warranty life estimates reflect 150,000 miles of use per PHEV and 100,000 miles of use for other EVs. Calendar-year lifetimes are calculated as multiples of first-year savings estimates of 855 thousand $\mathrm{tCO}_{2} \mathrm{e}$ total or $3.2 \mathrm{tCO}_{2} \mathrm{e}$ per vehicle. 


\section{Discussion}

Estimates indicate that the average first-year GHG reductions resulting from a rebated vehicle is approximately 3.2 metric tons of $\mathrm{CO}_{2} \mathrm{e}$ emissions per vehicle. The average estimated reductions for BEVs (3.5 tons) is higher than that for PHEVs (2.8 tons). As displayed above in Figure 1, the difference in reductions between PHEVs and BEVs change when vehicles are evaluated over their warranty life, with PHEV savings (31 tons) surpassing those of BEVs (29 tons). This is due to the higher number of miles $(150,000)$ covered by the battery warranty for PHEVs (required by California's Zero-Emission Vehicle Standards $[25,26]$ ) compared to the standard 100,000-mile battery warranty offered by most manufacturers for other EV technology types [27]. As described in Section 2.2.2, first-year reductions better illustrate the variations across vehicle types and consumer types that result from differences in annual mileage estimates or carbon intensity of fuels, while warranty-life reductions can be viewed as reductions achieved over the time period the vehicles should very reasonably be expected to last.

There is also variability in Rebate-Essential reductions between vehicle technology types ranging from $45 \%$ of PHEV reductions, $58 \%$ of BEV reductions, and $67 \%$ of FCEV reductions associated with Rebate-Essential participants (see Appendix E for further detail). This variability closely resembles that of the Consumer Survey results on Rebate Essentiality, which are presented in Appendix D.

In addition to the impacts of technology type on GHG reductions, emission reductions also varied across the three rebate types. For example, first-year savings for fleets are much lower than individuals (Figure 2), primarily due to the lower annual VMT assumed for fleet vehicles (see Appendix B). However, the variability in VMT—and therefore most of the variability in emission reductions-diminishes when quantifying emissions over the warranty life of vehicles, as this period is based on the 100,000-/150,000-mile warranty associated with the vehicle technology and does not vary by consumer type. Differences are also seen in Rebate-Essential reductions between Standard Rebates for individuals and Increased Rebates for Low-/Moderate-Income Individuals (see Appendix E), with 53\% of first-year reductions from Standard Rebates and 59\% from those from Increased Rebates associated with Rebate-Essential participants. Fleets have not been invited to participate in the Consumer Survey and therefore are not analyzed for Rebate-Essential reductions.

\subsection{Impact of Methodological Contributions}

A rough assessment of the benefits of using project-specific data and the other contributions of this work indicates significant impact, as the following illustrates: when the results from this work are filtered for individual MY 2017 BEVs and PHEVs to facilitate comparisons with prior public work [11], they produce average per-mile GHG reductions $20-60 \%$ greater than previous estimates. Once scaled up by first-year VMT assumptions, they produce per-vehicle reductions roughly $35-45 \%$ greater than prior public work. This is illustrated in Table 4 below.

Table 4. Comparison of Model Year 2017 GHG Reductions for Individuals.

\begin{tabular}{|c|c|c|c|c|}
\hline \multirow[b]{2}{*}{ Technology Type } & \multicolumn{2}{|c|}{$\begin{array}{l}2017 \text { Estimates for FY 2017-18 [11] } \\
\text { (MY 2017) }\end{array}$} & \multicolumn{2}{|c|}{$\begin{array}{l}\text { New Estimates for Life of Project } \\
\text { (MY } 2017 \text { subset) }\end{array}$} \\
\hline & $\begin{array}{l}\text { Avg. Reductions } \\
\text { Per Mile } \\
\left(\text { Grams } \mathrm{CO}_{2} \mathrm{e}\right)\end{array}$ & $\begin{array}{l}\text { Avg. First-Year } \\
\text { Reductions Per } \\
\text { Vehicle }\left(\mathrm{tCO}_{2} \mathrm{e}\right)\end{array}$ & $\begin{array}{l}\text { Avg. Reductions } \\
\text { Per Mile } \\
\left(\text { Grams } \mathrm{CO}_{2} \mathrm{e}\right)\end{array}$ & $\begin{array}{l}\text { Avg. First-Year } \\
\text { Reductions Per } \\
\text { Vehicle }\left(\mathrm{tCO}_{2} \mathrm{e}\right)\end{array}$ \\
\hline PHEV & 142 & 2.1 & $228(+60 \%)$ & $3.1(+45 \%)$ \\
\hline $\mathrm{BEV}$ & 247 & 2.7 & $296(+20 \%)$ & $3.7(+35 \%)$ \\
\hline
\end{tabular}




\subsection{Limitations and Next Steps}

It should be noted again that the GHG estimates in this work do not include timevariant carbon intensity or other factors that might impact results over time. Additionally, this work focuses on on-road and fuel life-cycle emissions and does not assess total vehicle life-cycle emissions (including those related to vehicle or battery production, maintenance and disposal) or any potential variability in emission rates due to climate effects. Further, this work uses individual vehicles as the unit of analysis and therefore behavior-change effects, such as vehicle substitution for certain trips, are not accounted for. Were they, some BEV emission savings would need to be reduced to account for conventional vehicle mileage used for trips not attempted in the BEV (particularly short-range BEVs prominent in early market commercialization). This need for a vehicle-substitution penalty is also expected to decline as BEV range capabilities improve. Research analyzing EV-owning household driving dynamics, such as that conducted by UC Davis [22], could be referenced to support an assessment of household-level impacts. Next steps to address these and other limitations are discussed further below.

\subsubsection{Project Eligibility Changes and Extrapolation of Results to Future Time Periods}

Because consumer and vehicle eligibility criteria change over time, care should be taken when extrapolating the results of this study to future time periods. As of 29 March 2016, higher-income consumers became ineligible to participate in CVRP, and on 1 November 2016, the eligibility criteria were adjusted. The income cap shifted participant demographics, with corresponding changes in vehicle preferences and adoption. As of 3 December 2019, an MSRP cap of USD 60,000 was instituted on all vehicles except FCEVs. The electric range requirement for PHEVs has also changed over time and is increasing to 30 miles in April 2021. For these reasons, the average emission reduction estimates associated with each participant and vehicle will likely change going forward from the period examined herein.

\subsubsection{Additional Project Data to Utilize}

Given the significant impact of using project-specific data and the other contributions of this work, further steps appear warranted. The analysis shows that emission reduction estimates are sensitive to deviations from assumed fuel consumption rates of the baseline fleet and VMT. Therefore, precision of the reduction estimate relies on the accuracy of these assumptions, revealing the opportunity to continue refinement with project-derived data.

To be consistent with [11] and to simplify the emission reduction calculations, it is assumed that had rebated-EVs not been acquired, participants would have purchased new gasoline vehicles instead. A more accurate baseline for evaluating the impact of the project could be calculated using a counterfactual fleet likely to exist in the project's absence. This counterfactual fleet could be derived from answers to the CVRP Consumer Survey. Specifically, from questions about whether rebated EVs replaced a household vehicle and what would have occurred if rebates for EVs were not available. A partial assessment of the impact of incorporating this data was conducted in a previous version of this work [44] by assigning counterfactual fuel consumption rate values to the subset of survey respondents who indicated that they both replaced a vehicle with their rebated EV and would not have made a vehicle purchase had CVRP rebates not been available. This resulted in a slight decrease in the first-year emission reductions compared to the primary estimate, indicating vehicles replaced by this cohort may be less-emitting on average than new gasoline vehicles. In other words, any increase in first-year emission reductions resulting from accounting for older conventional replaced vehicles may be offset by a decrease in emission reductions resulting from EVs replacing other clean-technology vehicles. A complete assessment of the impact of replaced vehicles on results can be explored by incorporating the remaining survey respondents and continuing to refine the related fuel consumption inputs.

The primary VMT assumptions used in this analysis were average VMT findings from surveys of EV drivers in California [22,23], which may not be an accurate representation 
of all CVRP participants. Consumer Survey respondents are asked how many miles are included in their lease and how many total miles they have driven their vehicle so far (albeit not long after vehicle acquisition). Answers to these questions, along with vehicle purchase/lease dates and survey started/submitted dates, could be explored for their value as case- and model-specific VMT metrics. VMT inputs could also be improved by employing a time-variance when estimating multi-year savings to address changes in driving behavior such as possible decreasing annual VMT over time.

As described in Section 2.2.3, Rebate-Essential reductions for non-respondents were accounted for using the average Rebate Essentiality percentage by project era and technology type. Sensitivity to these assumptions were tested using a margin of error of +/- 10 percentage points to account for potential survey biases. Consumer demographics and other survey variables can be explored for use in predictive modeling of Rebate Essentiality to address biases and more accurately account for the rebate influence on survey non-respondents.

Rebate Essentiality represents the most conservative measure of rebate influence available in survey data. However, indicators of rebate importance provide a more nuanced measure of rebate influence. For example, survey respondents are asked, "How important was the state vehicle rebate (CVRP) in making it possible for you to acquire your clean vehicle?" and provided options ranging from "Not at all important" to "Extremely important." Assessing "rebate-important" reductions would provide an additional measure of rebate influence between Rebate-Essential reductions and all rebated reductions.

\subsubsection{Conservatisms to Address and Other Considerations}

An assumption made to conservatively facilitate the emission reduction estimates was that electricity generation is properly represented by the 2015 LCFS regulation CI, which uses the average California electricity generation mix during 2010. This does not account for ongoing grid decarbonization as the state achieves its renewable-portfoliostandard (RPS) goals. Calculating emission reductions with the latest annual update of this metric, which uses grid inputs from 2018, resulted in an 8-9\% increase in savings. Even this can be considered a conservative grid assumption for longer-term accounting (e.g., warranty-life) of the newer vehicles analyzed. Using time-variant CI data for all fuels and assessing marginal emissions are additional next steps, which may result in further GHG benefits depending on the net effect of grid and gasoline decarbonization as California simultaneously achieves its RPS and LCFS goals. Further, case-specific CI data can be deployed based on utility-specific electricity CI and survey data related to household solar energy use.

CVRP is likely to have positive spillover effects on the EV market, which may lead to greater long-run benefits than the emission reductions estimated in this report. However, as suggested by one anonymous reviewer of a precursor work and explored in [45], this approach does not account for any national effects that might arise were rebated EVs not purchased, causing automakers to adapt by increasing the fuel efficiency of their conventional vehicle offerings in order to maintain overall compliance with national fueleconomy/emissions standards. This could raise the fuel efficiency of the counterfactual fleet, thereby reducing the emission savings attributable to the project.

Finally, prior work [46] has indicated Monte Carlo analysis is useful in prioritizing inputs for refinement based upon repeated calculations that simultaneously and probabilistically vary several input values. This approach could also be used to determine a probability distribution of emissions from the baseline and rebated fleets.

\section{Conclusions}

Prior estimates of GHG emission reductions associated with rebated battery and plugin hybrid electric vehicles in California were based upon average vehicle characterizations and intentionally conservative as a starting point for future refinement. This work aims to inform that process by utilizing project-derived and/or case-specific data and other 
enhancements to create a more detailed picture of the GHG impacts of 269,902 EV rebates disbursed through August 2018. Specifically, this study employed model- and model-yearspecific fuel consumption rates and PHEV model-specific electric-VMT percentages to estimate rebated-vehicle emissions. California-sales-weighted average fuel consumption rate values were created for each model year of baseline gasoline vehicles for comparison. It also uses disaggregated and weighted project survey data characterizing rebate influence to estimate both rebated reductions associated with the project and Rebate-Essential reductions attributable to the project.

Reductions from CVRP-rebated PHEVs, BEVx vehicles, BEVs, and FCEVs over the first year of vehicle operation are estimated to be approximately 855,000 metric tons of $\mathrm{CO}_{2}$-equivalent emissions, roughly $54 \%$ of which are classified as Rebate Essential. When scaled up to represent operation over a 100,000-/150,000-mile warranty life, total emission savings increase to 7.9 million metric tons.

A noteworthy observation relates to cost-effectiveness: comparing the warranty-life benefit of 7.9 million metric tons of GHG emissions reduced to the USD 603 million in corresponding rebates results in an estimate of roughly USD 76 of state rebate incentives per ton reduced over the 100,000-/150,000-mile warranty period, or about $13 \mathrm{~kg}$ of $\mathrm{CO}_{2}$ e saved over that period per incentive dollar invested. However, there is considerable uncertainty in these estimates which are heavily influenced by the generally conservative assumptions in this study.

First-year and warranty-life reductions average 2.8 and 31 tons per PHEV, 3.1 and 28 tons per BEVx, 3.5 and 29 tons per BEV, and 2.5 and 20 tons per FCEV, respectively. Compared to prior work, this approach was found to produce average first-year GHG reductions per vehicle that are roughly $35-45 \%$ greater, indicating the importance of ongoing refinement with more project-specific and detailed data. Sensitivity analyses highlight significant remaining uncertainty and indicate priority attention should be given to the fuel efficiency of the baseline (avoided) vehicle and assumed VMT. Unknown vehicle ownership and operational timeframes present further challenges in estimating lifetime emission savings. Additional unexplored opportunities include analyzing the effect of time-variant factors and counterfactual survey data.

Author Contributions: N.P.: Methodology, software, validation, formal analysis, investigation, data curation, writing — original draft preparation, writing—review and editing, visualization, project administration. B.D.H.W.: Conceptualization, methodology, validation, investigation, resources, data curation, writing — original draft preparation, writing — review and editing, visualization, supervision, project administration, funding acquisition. All authors have read and agreed to the published version of the manuscript.

Funding: This research was funded by a grant for the administration of the Clean Vehicle Rebate Project, a program of the California Air Resources Board (G17-CVRP-01, G18-CVRP-01, G19-CVRP$01)$. The funders were not involved in the conduct of the research.

Informed Consent Statement: Program participants agreed to the collection and anonymized use of data as a term and condition of program participation.

Data Availability Statement: Data analyzed for this study were collected as part of the administration of the Clean Vehicle Rebate Project and are not available in raw form to protect participant confidentiality and sensitive information. However, portions of the data are available for free download via program dashboards, as are a variety of analyses that shed additional light on its collection and qualities: http:/ / cleanvehiclerebate.org (accessed 24 June 2021).

Acknowledgments: This study was conducted by the Center for Sustainable Energy to inform the Clean Vehicle Rebate Project, and we thank CARB staff for the opportunity to contribute to the conversation. However, it does not necessarily represent the views of the California Air Resources Board. Nor does it represent a final determination for project-reporting purposes. The authors extend special thanks to James Tamerius for analytical guidance and editorial support. The authors also thank Keir Havel and Michelle Jones for providing research assistance, and others who provided feedback.

Conflicts of Interest: The authors declare no conflict of interest. 


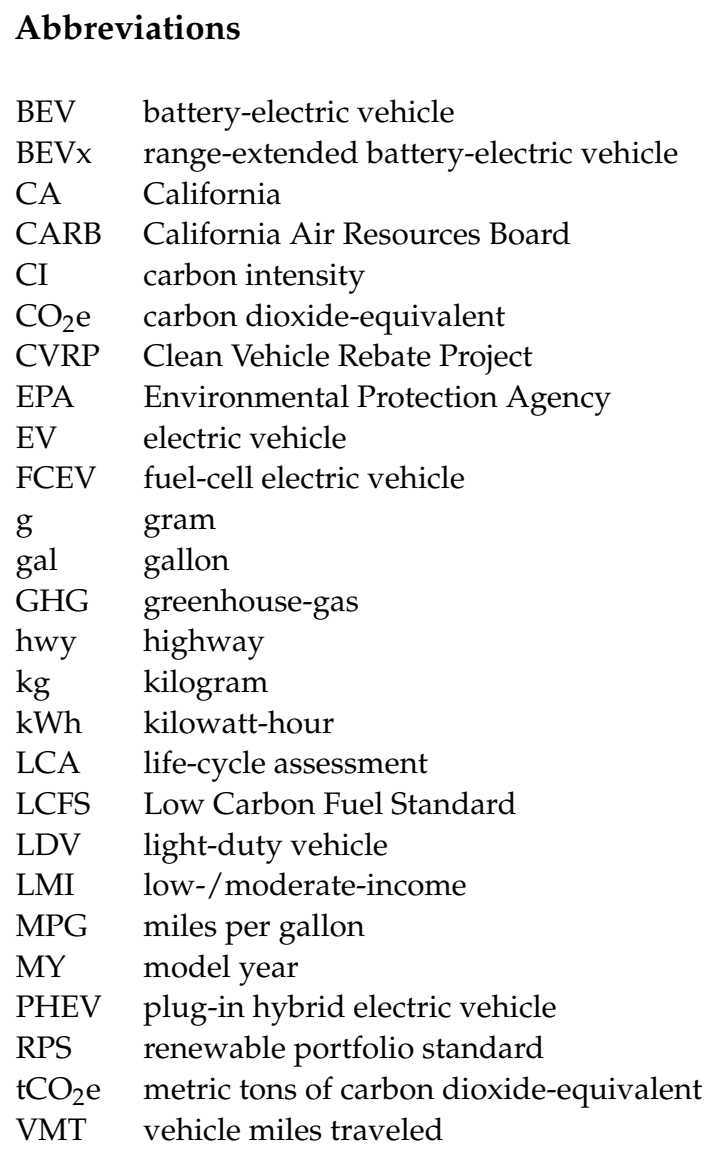

\section{Appendix A}

As detailed in Table 2 and discussed further in Section 3.2.1, baseline-vehicle fuel consumption rates are MY-specific. MYs 2011-2018 are comprised of California-salesweighted averages based on the EPA-adjusted fuel economy for the 30 top-selling new gasoline models (which include over $50 \%$ of sales for each model year). Vehicles within each MY were assessed at the model-level. For models with multiple trims or series with varying fuel efficiency within a given $M Y$, the most efficient (and therefore most conservative) fuel economy value was used in the sales-weighting calculations.

For MYs 2009-2010, for which sales data were not available, EPA-adjusted U.S.production-weighted car averages are used. These were found to represent average California fuel economy more closely than car-and-truck averages. Table A1 presents the baseline-vehicle fuel economy values from which fuel consumption rates were derived, with a comparison to the U.S.-production averages for cars (used for MYs 2009-2010) and for cars and trucks (used in sensitivity analysis). Fuel economy values in MPG were converted to fuel consumption rates in gallons per mile for analysis. 
Table A1. Baseline-Vehicle Fuel Economy Compared with U.S.-Production-Weighted Avg. Fuel Economy.

\begin{tabular}{|c|c|c|c|c|c|c|}
\hline \multirow{3}{*}{ Model Year } & \multicolumn{2}{|r|}{ Baseline Vehicle } & \multicolumn{4}{|c|}{ U.S.-Production-Weighted Avg. Fuel Economy [31,37] } \\
\hline & \multirow[b]{2}{*}{$\begin{array}{l}\text { Fuel Economy } \\
\text { (MPG) }\end{array}$} & \multirow[b]{2}{*}{ Description } & \multicolumn{2}{|c|}{ Car } & \multicolumn{2}{|c|}{ Car and Truck } \\
\hline & & & $\begin{array}{l}\text { Value } \\
\text { (MPG) }\end{array}$ & $\begin{array}{l}\text { Diff. from } \\
\text { Baseline }\end{array}$ & $\begin{array}{l}\text { Value } \\
\text { (MPG) }\end{array}$ & $\begin{array}{l}\text { Diff. from } \\
\text { Baseline }\end{array}$ \\
\hline 2009 & 25.4 & \multirow{2}{*}{$\begin{array}{l}\text { U.S.-production-weighted avg. } \\
\text { (car) [31] }\end{array}$} & 25.4 & n.a. & 22.4 & $-12 \%$ \\
\hline 2010 & 25.8 & & 25.8 & n.a. & 22.6 & $-12 \%$ \\
\hline 2011 & 25.1 & \multirow{9}{*}{$\begin{array}{l}\text { CA-sales-weighted avg. for the } 30 \\
\text { top-selling new gasoline } \\
\text { models (calculations using data } \\
\text { from }[21,30] \text { ) }\end{array}$} & 25.4 & $1 \%$ & 22.3 & $-11 \%$ \\
\hline 2012 & 27.9 & & 26.9 & $-3 \%$ & 23.6 & $-15 \%$ \\
\hline 2013 & 27.9 & & 27.7 & $-1 \%$ & 24.2 & $-13 \%$ \\
\hline 2014 & 28.2 & & 27.6 & $-2 \%$ & 24.1 & $-15 \%$ \\
\hline 2015 & 28.4 & & 28.2 & $-1 \%$ & 24.6 & $-13 \%$ \\
\hline 2016 & 28.7 & & 28.5 & $-1 \%$ & 24.7 & $-14 \%$ \\
\hline 2017 & 28.0 & & 29.2 & $4 \%$ & 25.2 & $-11 \%$ \\
\hline 2018 & 28.8 & & 29.9 & $4 \%$ & 25.4 & $-12 \%$ \\
\hline $2019^{1}$ & 28.8 & & - & - & - & - \\
\hline
\end{tabular}

${ }^{1}$ Model year 2018 value used due to limited 2019 data availability.

\section{Appendix B}

Due to limited public information about the driving characteristics of EVs in fleets, annual fleet VMT was inferred from federal fleet reporting for all passenger vehicles and the VMT characteristics of non-fleet EVs. Fleet PHEVs are characterized by the average annual VMT of all federal fleet passenger vehicles. Annual VMT for the other EV categories, which are more likely to have different usage from the average vehicle, are derived by scaling the average overall federal fleet value (used for PHEVs) down by the same magnitude observed for individuals.

Table A2. Description of Annual VMT Calculations for Fleets.

\begin{tabular}{|c|c|c|c|}
\hline \multirow{2}{*}{ Technology Type } & \multicolumn{2}{|c|}{ Fleets } & \multirow{2}{*}{$\begin{array}{c}\text { Individuals } \\
\text { Annual VMT }\end{array}$} \\
\hline & Annual VMT & Description & \\
\hline PHEV & 7768 & $\begin{array}{c}\text { Average of FY 2013-2017 } \\
\text { federal fleet passenger vehicle } \\
\text { annual VMT in [24] }\end{array}$ & 13,472 \\
\hline BEVx, Short Range BEV & 11,366 & $\begin{array}{l}\text { Fleet PHEV VMT decreased } \\
\text { by the magnitude observed } \\
\text { for } \\
\text { individuals: } 9207 \times\left(\frac{11,366}{13,472}\right)\end{array}$ & 11,366 \\
\hline Long Range BEV & 9196 & $\begin{array}{l}\text { Fleet PHEV VMT decreased } \\
\text { by the magnitude observed } \\
\text { for } \\
\text { individuals: } 9207 \times\left(\frac{13,456}{13,472}\right)\end{array}$ & 13,456 \\
\hline FCEV & 13,456 & $\begin{array}{l}\text { Fleet PHEV VMT decreased } \\
\text { by the magnitude observed } \\
\text { for } \\
\text { individuals: } 9207 \times\left(\frac{12,445}{13,472}\right)\end{array}$ & 12,445 \\
\hline
\end{tabular}

\section{Appendix C}

As described in Section 2.2.1, for PHEVs and BEVx vehicles (which use both electricity and gasoline as fuel) model-specific electric-VMT factors are used to assign fractions of total travel to electricity. Following the general approach in previous work [47], in cases where on-road studies of driving behavior have been conducted for specific rebated models, the electric-VMT findings from those studies are used (or averages of findings, for models with more than one study). For models that have not been studied, electric-VMT percentages are determined as a function of electric range, derived from plotting electric-VMT findings 
from studied models by their corresponding electric ranges. This plot, function, and relationship between the variables are presented in Figure A1.

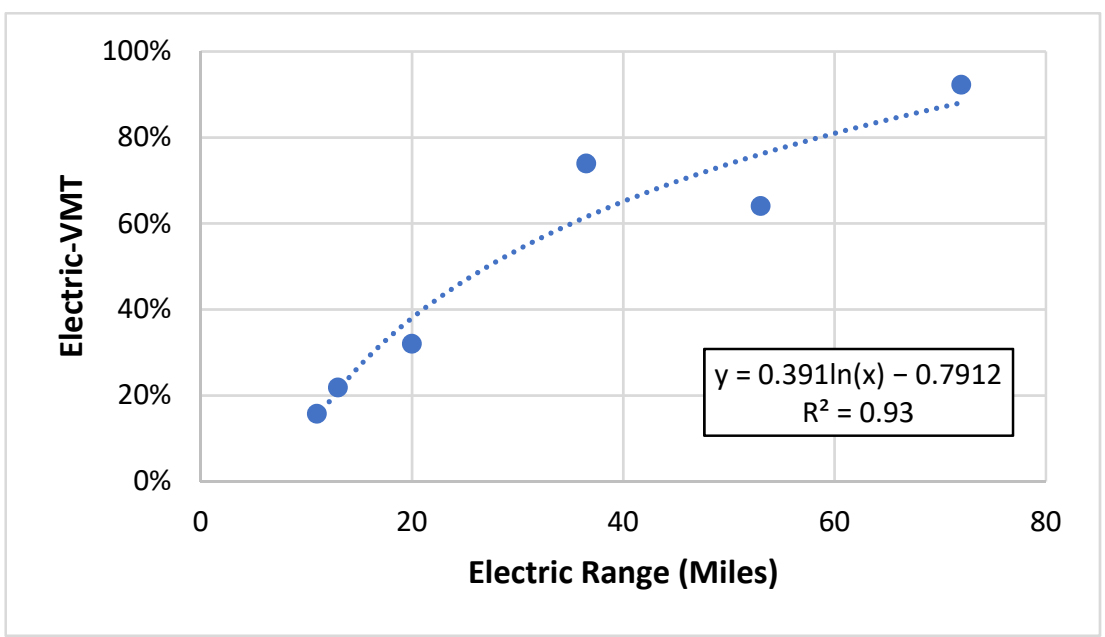

Figure A1. PHEV and BEVx Electric-VMT.

\section{Appendix D}

The weighted percentage of respondents from each Consumer Survey edition who indicated that they would not have purchased their EV without the CVRP rebate are presented in Table A3 below. These percentages reflect the proportion of GHG reductions categorized as "Rebate-Essential reductions" for project participants that did not respond to the Consumer Survey.

Table A3. Weighted Rebate Essentiality by Survey Edition and Technology Type.

\begin{tabular}{cccc}
\hline Technology Type & 2013-15 Edition & 2015-16 Edition & 2016-17 Edition \\
\hline PHEV & $41 \%$ & $47 \%$ & $47 \%$ \\
BEV /BEVx & $50 \%$ & $61 \%$ & $64 \%$ \\
FCEV & n.a. & n.a. & $67 \%$ \\
\hline
\end{tabular}

Note: Values are specific to the dataset used in this analysis and may not align with CVRP Rebate Essentiality percentages reported elsewhere. 


\section{Appendix E}

Table A4. GHG Reduction Estimates by Technology Type and Quantification Period.

\begin{tabular}{|c|c|c|c|}
\hline Technology Type & $\begin{array}{c}\text { Total Rebated } \\
\text { Reductions } \\
\left.\text { Thousand } \mathrm{tCO}_{2} \mathrm{e}\right)\end{array}$ & $\begin{array}{l}\text { Per-Vehicle } \\
\text { Reductions } \\
\qquad\left(\mathrm{tCO}_{2} \mathrm{e}\right)\end{array}$ & $\begin{array}{c}\text { Total } \\
\text { Rebate-Essential } \\
\text { Reductions } \\
\text { (Individuals only, } \\
\text { Thousand } \mathrm{tCO}_{2} \mathrm{e} \text { ) }\end{array}$ \\
\hline $\begin{array}{c}\text { PHEV( } \\
\mathrm{N}=104,583)\end{array}$ & $\begin{aligned} \mathrm{Y} 1 & =289 \\
\mathrm{WL} & =3235\end{aligned}$ & $\begin{array}{l}Y 1=2.8 \\
W L=31\end{array}$ & $\begin{aligned} \mathrm{Y} 1 & =127(45 \%) \\
\mathrm{WL} & =1418(45 \%)\end{aligned}$ \\
\hline $\begin{array}{c}\text { BEVx } \\
(\mathrm{N}=6559)\end{array}$ & $\begin{aligned} \mathrm{Y} 1 & =21 \\
\mathrm{WL} & =183\end{aligned}$ & $\begin{array}{r}Y 1=3.1 \\
W L=28\end{array}$ & $\begin{array}{c}\mathrm{Y} 1=12(61 \%) \\
\mathrm{WL}=107(61 \%)\end{array}$ \\
\hline $\begin{array}{c}\text { BEV } \\
(\mathrm{N}=154,184)\end{array}$ & $\begin{aligned} \mathrm{Y} 1 & =534 \\
\mathrm{WL} & =4432\end{aligned}$ & $\begin{array}{l}Y 1=3.5 \\
W L=29\end{array}$ & $\begin{aligned} \mathrm{Y} 1 & =301(58 \%) \\
\mathrm{WL} & =2471(58 \%)\end{aligned}$ \\
\hline $\begin{array}{c}\text { FCEV } \\
(\mathrm{N}=4576)\end{array}$ & $\begin{aligned} Y 1 & =11 \\
W L & =93\end{aligned}$ & $\begin{array}{l}Y 1=2.5 \\
W L=20\end{array}$ & $\begin{aligned} \mathrm{Y} 1 & =8(67 \%) \\
\mathrm{WL} & =60(67 \%)\end{aligned}$ \\
\hline $\begin{array}{c}\text { All } \\
(\mathrm{N}=269,902)\end{array}$ & $\begin{aligned} Y 1 & =855 \\
W L & =7944\end{aligned}$ & $\begin{array}{l}Y 1=3.2 \\
W L=29\end{array}$ & $\begin{aligned} \mathrm{Y} 1 & =448(54 \%) \\
\mathrm{WL} & =4057(53 \%)\end{aligned}$ \\
\hline
\end{tabular}

Note: Values may not sum to totals due to rounding. $Y 1=$ first year of vehicle operation, $W L=100,000-/ 150,000$ mile warranty life.

Table A5. GHG Reduction Estimates by Technology Type and Quantification Period.

\begin{tabular}{|c|c|c|c|}
\hline Technology Type & $\begin{array}{c}\text { Total Rebated } \\
\text { Reductions } \\
\text { (thousand } \mathrm{tCO}_{2} \mathrm{e} \text { ) }\end{array}$ & $\begin{array}{l}\text { Per-Vehicle } \\
\text { Reductions } \\
\quad\left(\mathrm{tCO}_{2} \mathrm{e}\right)\end{array}$ & $\begin{array}{c}\text { Total } \\
\text { Rebate-Essential } \\
\text { Reductions } \\
\text { (Individuals Only, } \\
\text { Thousand } \mathrm{tCO}_{2} \mathrm{e} \text { ) }\end{array}$ \\
\hline $\begin{array}{c}\text { Standard Rebatefor } \\
\text { Individuals } \\
(\mathrm{N}=251,960)\end{array}$ & $\begin{aligned} \mathrm{Y} 1 & =805 \\
\mathrm{WL} & =7416\end{aligned}$ & $\begin{array}{l}\mathrm{Y} 1=3.2 \\
\mathrm{WL}=29\end{array}$ & $\begin{aligned} \mathrm{Y} 1 & =429(53 \%) \\
\mathrm{WL} & =3885(52 \%)\end{aligned}$ \\
\hline $\begin{array}{l}\text { Low-/Moderate- } \\
\text { Income Increased } \\
\text { Rebate } \\
\text { for Individuals } \\
(\mathrm{N}=9859)\end{array}$ & $\begin{aligned} \mathrm{Y} 1 & =32 \\
\mathrm{WL} & =300\end{aligned}$ & $\begin{array}{l}\mathrm{Y} 1=3.2 \\
\mathrm{WL}=30\end{array}$ & $\begin{aligned} \mathrm{Y} 1 & =18(59 \%) \\
\mathrm{WL} & =172(57 \%)\end{aligned}$ \\
\hline $\begin{array}{l}\text { Fleet Rebate } \\
(\mathrm{N}=8083)\end{array}$ & $\begin{aligned} \mathrm{Y} 1 & =18 \\
\mathrm{WL} & =228\end{aligned}$ & $\begin{array}{l}Y 1=2.2 \\
W L=28\end{array}$ & n.a. \\
\hline $\begin{array}{c}\quad \text { All } \\
(N=269,902)\end{array}$ & $\begin{aligned} \mathrm{Y} 1 & =855 \\
\mathrm{WL} & =7944\end{aligned}$ & $\begin{array}{l}Y 1=3.2 \\
W L=29\end{array}$ & $\begin{aligned} \mathrm{Y} 1 & =448(54 \%) \\
\mathrm{WL} & =4057(53 \%)\end{aligned}$ \\
\hline
\end{tabular}

Note: Values may not sum to totals due to rounding. $Y 1=$ first year of vehicle operation, $\mathrm{WL}=100,000-/ 150,000$ mile warranty life.

\section{References}

1. Nealer, R.; Hendrickson, T.P. Review of Recent Lifecycle Assessments of Energy and Greenhouse Gas Emissions for Electric Vehicles. Curr. Sustain. Renew. Energy Rep. 2015, 2, 66-73. [CrossRef]

2. Marmiroli, B.; Messagie, M.; Dotelli, G.; Van Mierlo, J. Electricity generation in LCA of electric vehicles: A review. Appl. Sci. 2018, 8, 1384. [CrossRef]

3. Lattanzio, R.K.; Clark, C.E. Environmental Effects of Battery Electric and Internal Combustion Engine Vehicles; Congressional Research Service: Washington, DC, USA, 2020.

4. National Research Council. Transitions to Alternative Vehicles and Fuels; National Academies Press: Washington, DC, USA, 2013 [CrossRef]

5. Babaee, S.; Nagpure, A.S.; Decarolis, J.F. How much do electric drive vehicles matter to future U.S. emissions? Environ. Sci. Technol. 2014, 48, 1382-1390. [CrossRef]

6. Archsmith, J.; Kendall, A.; Rapson, D. From Cradle to Junkyard: Assessing the Life Cycle Greenhouse Gas Benefits of Electric Vehicles. Res. Transp. Econ. 2015, 52, 72-90. [CrossRef] 
7. Lutsey, N. Global Climate Change Mitigation Potential from a Transition to Electric Vehicles; ICCT: Washington, DC, USA, 2015.

8. National Academies of Sciences, Engineering, and Medicine. Zero Emission Vehicles: Forecasting Fleet Scenarios and their Emissions Implications; The National Academies Press: Washington, DC, USA, 2019. [CrossRef]

9. Brown, A.L.; Sperling, D.; Austin, B.; DeShazo, J.; Fulton, L.; Lipman, T.; Murphy, C.; Daniel Saphores, J.; Tal, G. Driving California's Transportation Emissions to Zero; UC Office of the President: University of California Institute of Transportation Studies: Oakland, CA, USA, 2021. [CrossRef]

10. Gohlke, D.; Zhou, Y. Assessment of Light-Duty Plug-In Electric Vehicles in the United States, 2010-2019; United States Department of Energy Office of Scientific and Technical Information (OSTI): Oak Ridge, TN, USA, 2020. [CrossRef]

11. California Air Resources Board. Proposed Fiscal Year 2017-18 Funding Plan for Clean Transportation Incentives. 2017. Available online: https:/ / ww2.arb.ca.gov/sites/default/files/classic/msprog/aqip/fundplan/proposed_1718_funding_plan_final.pdf (accessed on 30 July 2018).

12. California Air Resources Board. EMFAC2014 Web Database. 2014. Available online: https://www.arb.ca.gov/emfac/2014/ (accessed on 30 July 2018).

13. California Air Resources Board. LCFS Pathway Certified Carbon Intensities. Available online: https://www.arb.ca.gov/fuels/ lcfs / fuelpathways/pathwaytable.htm (accessed on 30 July 2018).

14. California Air Resources Board. Low Carbon Fuel Standard Regulation. 2015. Available online: https://www.arb.ca.gov/regact/ 2015/lcfs2015/lcfsfinalregorder.pdf (accessed on 30 July 2018).

15. California Air Resources Board. Proposed Fiscal Year 2016-2017 Funding Plan for Low Carbon Transportation and Fuels Investments and the Air Quality Improvement Program, Appendix A-Emission Reductions: Quantification Methodology. 2016. Available online: https:/ / www.arb.ca.gov/msprog/aqip/fundplan/proposed_fy16-17_fundingplan_appa.pdf (accessed on 30 July 2018).

16. Johnson, C.; Williams, B. Characterizing Plug-In Hybrid Electric Vehicle Consumers Most Influenced by California's Electric Vehicle Rebate. Transp. Res. Rec. 2017, 2628, 23-31. [CrossRef]

17. Williams, B.; Anderson, J. Strategically Targeting Plug-in Electric Vehicle Rebates and Outreach Using Characteristics of "Rebate-Essential" Consumers in 2016-2017. In Proceedings of the 31st International Electric Vehicles Symposium, Kobe, Japan, 30 September-3 October 2018.

18. Clean Vehicle Rebate Project. Income Eligibility. Available online: https://cleanvehiclerebate.org/eng/income-eligibility (accessed on 3 December 2020).

19. California Air Resources Board. Low Carbon Fuel Standard Regulation. 2018. Available online: https://www.arb.ca.gov/regact/ 2018/lcfs18/frolcfs.pdf (accessed on 30 May 2019).

20. California Air Resources Board. Low Carbon Fuel Standard Annual Updates to Lookup Table Pathways. 2020. Available online: https: / /ww3.arb.ca.gov/fuels/lcfs/fuelpathways / comments / tier2/elec_update.pdf?_ga=2.23020219.126207149.15875 98652-1818811838.1579023467 (accessed on 4 May 2020).

21. Fuel Economy Data. United States Department of Energy and United States Environmental Protection Agency. Available online: https: / / www.fueleconomy.gov / feg/download.shtml (accessed on 30 July 2018).

22. Tal, G.; Raghavan, S.S.; Karanam, V.C.; Favetti, M.P.; Sutton, K.M.; Lee, J.H.; Nitta, C.; Kurani, K.; Chakraborty, D.; Michael, N.; et al. Advanced Plug-in Electric Vehicle Travel and Charging Behavior Final Report; California Air Resources Board: Sacramento, CA, USA, 2019.

23. Hardman, S. Understanding the Early Adopters of Fuel Cell Vehicles; California Department of Transportation: Sacramento, CA, USA, 2019. [CrossRef]

24. U.S. General Services Administration. FY 2017 Federal Fleet Report. 2018. Available online: https://www.gsa.gov/policyregulations / policy/vehicle-management-policy / federal-fleet-report (accessed on 15 March 2019).

25. Zero-Emission Vehicle Standards for 2009 through 2017 Model Year Passenger Cars, Light-Duty Trucks, and Medium-Duty Vehicles, 13 CCR § 1962.1. Available online: https:/ / ww2.arb.ca.gov/sites/default/files/2019-07/cleancomplete \%20lev-ghg\%20 regs\%2010-19.pdf (accessed on 17 April 2020).

26. Zero-Emission Vehicle Standards for 2018 and Subsequent Model Year Passenger Cars, Light-Duty Trucks, and Medium-Duty Vehicles, 13 CCR § 1962.2. Available online: https:/ / ww2.arb.ca.gov/sites/default/files/2019-07/cleancomplete\%20lev-ghg\%20 regs\%2010-19.pdf (accessed on 17 April 2020).

27. United States Office of Energy Efficiency and Renewable Energy. Electric Car Safety, Maintenance, and Battery Life. Available online: https:/ / www.energy.gov / eere/electricvehicles/electric-car-safety-maintenance-and-battery-life\#: \{\}:text=Like\%20the \% 20engines\%20in \%20conventional,5\%20years\%20or\%2060\%2C000\%20miles. (accessed on 3 June 2020).

28. PluginCars.com. All the News, Reviews, Guides and Reports on Electric Cars. Available online: https://www.plugincars.com/ archives (accessed on 15 February 2018).

29. Car and Driver. Reviews. Available online: https:/ / www.caranddriver.com/reviews / (accessed on 15 February 2018).

30. Monthly New Vehicle Registration Data. IHS Markit. 2018. Available online: https:/ / ihsmarkit.com/index.html (accessed on 17 September 2018).

31. United States Environmental Protection Agency. Light-Duty Automotive Technology, Carbon Dioxide Emissions, and Fuel Economy Trends: 1975 through 2017. 2018. Available online: https:/ / nepis.epa.gov/Exe/ZyPDF.cgi?Dockey=P100TGDW.pdf (accessed on 30 July 2018). 
32. California Air Resources Board. California's Advanced Clean Cars Midterm Review, Appendix G: Plug-in Electric Vehicle In-Use and Charging Data Analysis. 2017. Available online: https://ww2.arb.ca.gov/sites/default/files/2020-01/appendix_g_pev_in_ use_and_charging_data_analysis_ac.pdf (accessed on 30 July 2018).

33. Idaho National Laboratory. Plug-in Electric Vehicle and Infrastructure Analysis. 2015. Available online: https:/ / inldigitallibrary. inl.gov/sites/sti/sti/6799570.pdf (accessed on 30 July 2018).

34. Carlson, B. Electric Vehicle Mile Traveled (eVMT): On-Road Results and Analysis. 2015. Available online: http://energy.gov/ sites/prod/files/2015/07/f24/vss171_carlson_2015_p.pdf (accessed on 30 July 2018).

35. Duhon, A.; Sevel, K.; Tarnowsky, S.; Savagian, P. Chevrolet Volt Electric Utilization. SAE Int. J. Altern. Powertrains 2015, 4, 269-276. [CrossRef]

36. Boston, D.; Werthman, A. Plug-in Vehicle Behaviors: An analysis of charging and driving behavior of Ford plug-in electric vehicles in the real world. World Electr. Veh. J. 2016, 8, 926-935. [CrossRef]

37. United States Environmental Protection Agency. Light-Duty Automotive Technology, Carbon Dioxide Emissions, and Fuel Economy Trends: 1975 through 2018. 2019. Available online: https://www.epa.gov/automotive-trends/download-automotivetrends-report\#Report-Tables (accessed on 27 August 2019).

38. Nicholas, M.A.; Tal, G.; Turrentine, T.S. Advanced Plug-in Electric Vehicle Travel and Charging Behavior Interim Report. 2017. Available online: https:/ / itspubs.ucdavis.edu/index.php/research/publications/publication-detail/?pub_id=2692 (accessed on 30 July 2018).

39. United States Environmental Protection Agency. eGRID Summary Tables 2018. 2020. Available online: https:/ /www.epa.gov / sites/production/files/2020-01/documents/egrid2018_summary_tables.pdf (accessed on 1 April 2020).

40. California Air Resources Board. Proposed Fiscal Year 2019-20 Funding Plan for Clean Transportation Incentives. 2019. Available online: https: / /ww2.arb.ca.gov/sites/default/files/2019-09/fy1920fundingplan-appa.pdf (accessed on 4 May 2020).

41. National Renewable Energy Laboratory. Predictive Models of Li-Ion Battery Lifetime. 2014. Available online: https: / afdc.energy. gov/fuels/electricity_benefits.html (accessed on 4 May 2020).

42. Demuro, D. Buying a Car: How Long Can You Expect a Car to Last? 2019. Available online: https:/ /www.autotrader.com/carshopping/buying-car-how-long-can-you-expect-car-last-240725 (accessed on 4 February 2021).

43. Auto Alliance. In Your State: State Facts. Available online: https://autoalliance.org/in-your-state/CA (accessed on 31 March 2020).

44. Pallonetti, N.; Williams, B. Exploratory Estimation of Greenhouse-Gas Emission Reductions Associated with California's Clean Vehicle Rebate Project. In Proceedings of the Transportation Research Board 2019 Annual Meeting, Washington, DC, USA, 13-17 January 2019.

45. Jenn, A.; Azevedo, I.M.L.; Michalek, J.J. Alternative Fuel Vehicle Adoption Increases Fleet Gasoline Consumption and Greenhouse Gas Emissions under United States Corporate Average Fuel Economy Policy and Greenhouse Gas Emissions Standards. Environ. Sci. Technol. 2016, 50, 2165-2174. [CrossRef] [PubMed]

46. Williams, B.; DeShazo, J. Pricing Workplace Charging: Financial Viability and Fueling Costs. Transp. Res. Rec. J. Transp. Res. Board 2014, 2454, 68-75. [CrossRef]

47. California Air Resources Board. Assessment of CARB's Zero-Emission Vehicle Programs Per Senate Bill 498. 2020. Available online: https:/ / ww3.arb.ca.gov / programs/zev/SB-498-Report-072320.pdf (accessed on 3 December 2020). 